\title{
FROM SELF-EVALUATION TO SELF-REFLECTION: TEACHERS' PERSPECTIVES
}

\author{
Noor Abidah Mohd. Omar, Masdinah Alauyah Md. Yusof and Abdul Halim Abdul \\ Raof \\ Universiti Teknologi Malaysia
}

\begin{abstract}
Teachers have been said to be the backbone that will determine the future of the country and the success of Malaysia's plan to be a developed nation by the year 2020. In order to improve students' performance in schools, teachers are required to be 'innovative, creative' and prepared for any changes. Teachers, especially in the Malaysian context, are thus encouraged to enhance and enrich their teaching competency in order to deliver better and more effective teaching, especially if this has to be done using the English language. By enhancing and enriching teachers' own competency in the language, teachers themselves will make the classroom teaching and learning process much more effective and efficient. This paper thus discusses the experience of a group of teachers at a boarding school in enhancing and enriching their language competence in teaching, using English as a medium of instruction by participating in a three-month course. It especially highlights the influence the course has on the teachers by reflecting on their proficiency, motivation and confidence in the language before, during and after the course. Feedback was obtained using three survey forms to accommodate the three phases of the course. Findings are mainly based on the teachers' perspectives from evaluating their own competency (before the course) and to what they realised (after the course). Observations from the trainers in terms of the participants' attendance, commitment, enthusiasm and interest in carrying out the tasks given are also discussed.
\end{abstract}

\section{KEY WORDS: IN-SERVICE TEACHER TRAINING, TEACHER MOTIVATION, TEACHING SCIENCE AND MATHEMATICS IN ENGLISH}

\section{INTRODUCTION}

Teachers are said to be the backbone that will determine the future of the country and the success of Malaysia's plan to be a developed nation by the year 2020. To achieve the goal of the National Education Policy towards the country's transformation programme by 2020 , all parties will have to work together actively to ensure quality human resources are produced. In line with this, Datuk Alexander Nanta Linggi, the Deputy Minister of Rural and Regional Development, emphasized that "teachers need to help produce quality students who can meet the nation's needs within the seven years left to achieve the vision" (Ling, 2013). Although it is a big challenge for the teachers in Malaysia, he said that teachers can help provide holistic education to students so that they are excellent in not only academics but also co-curricular activities. The same view was also posted by the Director of the Sarawak Education Department, Abdillah Adam. He argued that "Teachers are entrusted with the heavy responsibility of human resource development through systematic education, in line with the national aspiration of producing a knowledgeable and technology-savvy generation to meet the national aspiration of Malaysia as an advanced country by 2020" (Ling, 2013). 
Hence, to improve students' performance in schools, teachers need to be 'innovative', 'creative' and 'prepared' for any changes as only the 'quality and innovative' teachers will produce 'quality' students. Therefore, it is important that teachers in Malaysia should enhance and enrich their teaching competency in order to deliver better and more effective teaching, especially if this has to be done using the English language. By enhancing and enriching teachers' own competency in the language, teachers themselves will make the classroom teaching and learning process much more effective and efficient.

This paper, thus, discusses the experience of a group of teachers at one boarding school in enhancing and enriching their language competence in teaching, using English as a medium of instruction by participating in a three-month course. It especially highlights the influence the course has on the teachers by reflecting on their proficiency, motivation and confidence in the language before, during and after the course. Feedback was obtained using three survey forms to accommodate the three phases of the course. Findings are mainly based on the teachers' perspective from evaluating their own competency (before the course) and to what they realized (after the course). Observations from the trainers in terms of the participants' attendance, commitment, enthusiasm and interest in carrying out the tasks given are also discussed.

\section{Teachers' Language Competence}

Regardless of the subject a teacher teaches, without good communicative language, a classroom teaching will fail. All aspects related to teaching, from delivering input to assessing students, require a teacher to be competent in the language of instruction. Mariage, Englert, \& Garmon (2000) stated that language is a critical and pervasive component of pedagogical practice as every aspect of a teacher's work relies on the effective use of language.

Quality teaching does not only depend on a teacher's knowledge of the subject-matter but also his/her language proficiency (Council of Ministers of Education, Canada, 2013). Teachers' and students' interactions often affect students' academic performance in terms of their engagement and interest in learning (Crosnoe, Johnson, \& Elder, 2004). Hence, the Council of Ministers of Education further argued that positive interactions with students could only be fostered if teachers have excellent communication skills and are competent users of the language of instruction.

\section{Teachers' Self-Efficacy}

According to Bandura (1977, cited in Fajares, 2002 ), people often behave based on the beliefs they hold about their own capabilities than what they are actually capable of accomplishing. Fajares (2002) stated that "self-efficacy beliefs affect behaviour in several important ways; these beliefs can influence the choices individuals make and the courses of action they pursue". In addition, "individuals will also engage themselves in tasks which they feel competent and confident in and will avoid those in which they do not". Fajares also said that "efficacy beliefs help determine how much effort people will expend on an activity, how long they will persevere when confronting obstacles, and how resilient they will be in the face of adverse situations; the higher the sense of efficacy, the greater the effort, persistence, and resilience". Hence, as stated by Eslami and Fatahi (2008), a teacher's self-efficacy can strongly influence the teaching practices and learning outcomes. 


\section{Teacher's Motivation}

Motivation plays a vital role in learning a language. To ensure students would be motivated to learn a subject taught in English, teachers should also show their motivation to teach the subject in English. The students' performance in relation to educational aims and objectives is often associated with teachers' motivation to teach (Adeyinka, Asabi and Adedotun, 2013). There are many factors affecting a teacher's motivation to teach. Among them are a teacher's personal and social factors, classroom environment, socio economic status, student's behaviour, examination stress, rewards and incentives, self-confidence and teacher's personality (Alam and Farid, 2011).

\section{In-service Teacher Training Program}

Alam and Farid (2011) stated that since teachers are the backbone of the educational institutes and the future of a nation lies in their hands, teacher training programmes are vital to help improve the quality of education. They also recommended that no teachers should be appointed without a professional training in education and that refresher and in service courses should be arranged for the teachers at regular time intervals as it will update the teachers in the contents of the related subjects as well as in the area of teaching skills. In line with this recommendation, Nyakundi (2012) found in her study that teachers agreed teacher training improves their job satisfaction and their performance. Thus, she recommended that teachers should attend in-service training to update their skills because the trainings can help teachers develop confidence in teaching their subjects and become motivated.

\section{METHODOLOGY}

\section{The Study}

This paper reports on a study based on a three-month training for a group of secondary school teachers from a boarding school in Johor. The main purpose of the training was to enhance the confidence level of the teachers in teaching school subjects and in communicating with colleagues using English language. In addition, the purpose was also to enable teachers to communicate more effectively in order to help students understand lessons better. It was also the hope of the school administrators that the training could raise awareness and improve practice on effective instructional strategies among teachers participating.

Five experienced TESL-trained lecturers conducted the training, which focused on the forms and functions of the English language used in delivering lessons and in managing classroom activities. These trainers have had about 20 years of teaching experience. The table below summarises the topics covered in the training. 
Table 1: Topics covered in the training

\begin{tabular}{|l|}
\hline Topic \\
\hline Starting a lesson \\
\hline Delivering content of a lesson \\
\hline Ending a lesson \\
\hline Teacher questioning strategies \\
\hline Classroom communication strategies \\
\hline Handling students' questions \\
\hline Managing classroom situations \\
\hline
\end{tabular}

The typical approach used in the training was using the Input - Activities - Task model. Input on a certain topic was delivered to participants as a lead-in before participants engaged themselves in pedagogical activities. What followed next was a task which reflected actual classroom task such as 'starting a lesson'.

The training culminated in the participants delivering a micro teaching of an actual lesson conducted in English to fellow participants. The trainers and fellow participants provided feedback on the delivery and suggested possible improvements.

\section{Participants of the Study}

The participants of the study comprised 26 teachers; 13 male and 13 female. Based on the initial discussion with the school administrator, the course was intended for teachers teaching Science and Mathematics. However, teachers for other subjects were also part of the group. There were eventually among others, those teaching Bahasa Malaysia, Islamic Education and Geography. No English language teachers participated in this study. The participants' age ranged between 25 and 55 years. Detailed profiles of the participants are shown in Table 2 and Table 3 below.

Table 2: Profile of participants - Subject taught

\begin{tabular}{|l|l|l|l|}
\hline Subject taught & Male & Female & Total \\
\hline Mathematics & 1 & 4 & 5 \\
\hline Physics & 2 & 3 & 5 \\
\hline Chemistry & 2 & 2 & 4 \\
\hline Biology & 2 & 1 & 3 \\
\hline Bahasa Malaysia & 1 & 1 & 2 \\
\hline Computer & 1 & 1 & 2 \\
\hline Islamic Education & - & 1 & 1 \\
\hline Science & 1 & - & 1 \\
\hline Career Guidance & 1 & - & 1 \\
\hline Geography & 1 & - & 1 \\
\hline KHB & 1 & - & 1 \\
\hline Total & 13 & 13 & 26 \\
\hline
\end{tabular}


Table 3: Profile of participants - Teaching experience and Age

\begin{tabular}{|l|l|l|l|l|}
\hline & \multicolumn{5}{|l|}{ Years of Teaching Experience } \\
\hline Gender & $1-5$ & $6-10$ & $11-15$ & $>15$ \\
\hline Male & 1 & 4 & 2 & 4 \\
\hline Female & 1 & 9 & 2 & 1 \\
\hline & Age \\
& \multicolumn{4}{l}{} \\
\hline Gender & $25-29$ & $30-35$ & $36-40$ & $>45$ \\
\hline Male & 2 & 5 & 2 & 3 \\
\hline Female & 3 & 7 & 1 & 1 \\
\hline
\end{tabular}

\section{Instruments of the Study}

Three sets of questionnaires were used to gather information on the influence the course had on the participants in terms of their motivation and confidence in using English in their teaching, by reflecting on their English language proficiency level.

Observations were also made by the five trainers conducting the course. These were in the form of the participants' commitment, enthusiasm, and interest in carrying out the tasks given.

\section{Procedure of the Study}

The course was held once a week in the afternoon after school hours. Each training session lasted between two and three hours. At the beginning of the first session, the first set of questionnaires was distributed. This was to find out the teachers' perception of their own language skills abilities. This was the self-evaluation part of the course.

The second set of questionnaires was distributed at about halfway through the course (See Appendix). The aim was to determine if the course content was suitable and if their challenges had been minimized. The respondents were again asked to self-evaluate.

The last set of questionnaires was given to the participants during the last session. Like the initial survey, the purpose of distributing this last set was to gain insight into the effectiveness of the course by asking the teachers to reflect on what they had experienced in the course.

Throughout the course, the trainers took attendance and noted responses of the participants. Their questions in relation to challenges and difficulties they faced during teaching were also noted and as much as possible answered. Table 4 below lists some of the challenges the participants faced.

Table 4: Challenges faced by participants

\begin{tabular}{|l|}
\hline Lack of confidence among teachers in using English to teach \\
\hline Difficulty in elaborating ideas in lessons taught \\
\hline Students' lack of proficiency in English, affecting understanding of lessons taught in English \\
\hline Environment not too supportive of teachers using English \\
\hline
\end{tabular}




\section{FINDINGS AND DISCUSSION}

This section of the paper presents the findings from the three sets of questionnaires given. However, it mainly reports on the input obtained from the open-ended questions in the questionnaires and not the quantitative data. Observations by the trainers are also discussed.

At the beginning of the first session, the teachers were first asked to rate themselves in terms of their competencies in the four skills: Reading, Listening, Speaking and Writing (questionnaire 1). This was aimed at gaining some insight into the teachers' perception of their 'ability' prior to the commencement of the course. It also served as a form of 'needs analysis' in the form of teachers' self-evaluation. The results based on their teaching experience are shown in the following tables: Tables 5-8.

Table 5: Teachers' Perception of their Reading Competency

\begin{tabular}{|l|l|l|l|l|l|l|l|l|l|}
\hline \multirow{2}{*}{$\begin{array}{l}\text { Reading } \\
\text { competency }\end{array}$} & \multicolumn{6}{|l|}{ Years of teaching experience } \\
\cline { 2 - 11 } & $1-5$ & \multicolumn{2}{|l|}{$6-10$} & \multicolumn{2}{l|}{$11-15$} & \multicolumn{2}{l|}{$>15$} & \multicolumn{2}{l|}{ Total } \\
\cline { 2 - 10 } & $\mathrm{M}$ & $\mathrm{F}$ & $\mathrm{M}$ & $\mathrm{F}$ & $\mathrm{M}$ & $\mathrm{F}$ & $\mathrm{M}$ & $\mathrm{F}$ & \\
\hline Poor & & & 1 & & & & 1 & & 2 \\
\hline Average & 1 & & 3 & 1 & 2 & 1 & & 1 & 9 \\
\hline Good & & $\mathbf{1}$ & & $\mathbf{7}$ & & $\mathbf{1}$ & $\mathbf{3}$ & & $\mathbf{1 2}$ \\
\hline Excellent & & & & 1 & & & & & 1 \\
\hline Total & 1 & 1 & 4 & 9 & 2 & 2 & 4 & 1 & 24 \\
\hline
\end{tabular}

Table 6: Teachers' Perception of their Writing Competency

\begin{tabular}{|l|l|l|l|l|l|l|l|l|l|}
\hline \multirow{2}{*}{$\begin{array}{l}\text { Writing } \\
\text { competency }\end{array}$} & \multicolumn{6}{|l|}{ Years of teaching experience } \\
\cline { 2 - 10 } & $1-5$ & \multicolumn{2}{|l|}{$6-10$} & \multicolumn{2}{|l|}{$11-15$} & \multicolumn{2}{l|}{$>15$} & Total \\
\cline { 2 - 10 } & $\mathrm{M}$ & $\mathrm{F}$ & $\mathrm{M}$ & $\mathrm{F}$ & $\mathrm{M}$ & $\mathrm{F}$ & $\mathrm{M}$ & $\mathrm{F}$ & \\
\hline Poor & & & 2 & & 2 & & 1 & 1 & 6 \\
\hline Average & & $\mathbf{1}$ & $\mathbf{2}$ & $\mathbf{7}$ & & $\mathbf{1}$ & $\mathbf{2}$ & & $\mathbf{1 3}$ \\
\hline Good & 1 & & & 2 & & 1 & 1 & & 5 \\
\hline Total & 1 & 1 & 4 & 9 & 2 & 2 & 4 & 1 & 24 \\
\hline
\end{tabular}


Table 7: Teachers' Perception of their Speaking Competency

\begin{tabular}{|l|l|l|l|l|l|l|l|l|l|}
\hline \multirow{2}{*}{$\begin{array}{l}\text { Speaking } \\
\text { competency }\end{array}$} & \multicolumn{6}{|l|}{ Years of teaching experience } \\
\cline { 2 - 10 } & $1-5$ & \multicolumn{2}{|l|}{$6-10$} & \multicolumn{2}{l|}{$11-15$} & \multicolumn{2}{l|}{$>15$} & Total \\
\cline { 2 - 10 } & $\mathrm{M}$ & $\mathrm{F}$ & $\mathrm{M}$ & $\mathrm{F}$ & $\mathrm{M}$ & $\mathrm{F}$ & $\mathrm{M}$ & $\mathrm{F}$ & \\
\hline Poor & & & 3 & & 1 & & 2 & 1 & 7 \\
\hline Average & $\mathbf{1}$ & $\mathbf{1}$ & $\mathbf{1}$ & $\mathbf{8}$ & & $\mathbf{2}$ & $\mathbf{2}$ & & $\mathbf{1 5}$ \\
\hline Good & & & & 1 & 1 & & & & 2 \\
\hline Total & 1 & 1 & 4 & 9 & 2 & 2 & 4 & 1 & 24 \\
\hline
\end{tabular}

Table 8: Teachers' Perception of their Listening Competency

\begin{tabular}{|l|l|l|l|l|l|l|l|l|l|}
\hline \multirow{2}{*}{$\begin{array}{l}\text { Listening } \\
\text { competency }\end{array}$} & \multicolumn{6}{|l|}{ Years of teaching experience } \\
\cline { 2 - 10 } & $1-5$ & \multicolumn{2}{|l|}{$6-10$} & \multicolumn{2}{l|}{$11-15$} & \multicolumn{2}{l|}{$>15$} & Total \\
\cline { 2 - 10 } & $\mathrm{M}$ & $\mathrm{F}$ & $\mathrm{M}$ & $\mathrm{F}$ & $\mathrm{M}$ & $\mathrm{F}$ & $\mathrm{M}$ & $\mathrm{F}$ & \\
\hline Poor & & & 1 & & & & 2 & & 3 \\
\hline Average & & & $\mathbf{3}$ & $\mathbf{5}$ & $\mathbf{2}$ & $\mathbf{2}$ & $\mathbf{1}$ & $\mathbf{1}$ & $\mathbf{1 4}$ \\
\hline Good & 1 & 1 & & 3 & & & 1 & & 6 \\
\hline Excellent & & & & 1 & & & & & 1 \\
\hline Total & 1 & 1 & 4 & 9 & 2 & 2 & 4 & 1 & 24 \\
\hline
\end{tabular}

Generally, majority of the participants perceived that their reading competency is 'Good' while for speaking, listening and writing competencies, they rated themselves as 'Average'. Results tabulated based on their specialisations also showed the same outcome.

In terms of their confidence in using English, almost 50\% of the participants were unsure of their confidence (based on their teaching experience) as shown in the table below. More than $50 \%$ are those with 6-10 years of teaching experience. 
Table 9: Teachers' Perception of their Confidence in using English

\begin{tabular}{|l|l|l|l|l|l|l|l|l|l|}
\hline & \multicolumn{9}{|l|}{ Years of teaching experience } \\
\cline { 2 - 11 } & $1-5$ & \multicolumn{2}{|l|}{$6-10$} & \multicolumn{2}{l|}{$11-15$} & \multicolumn{2}{l|}{$>15$} & Total \\
\cline { 2 - 11 } & $\mathrm{M}$ & $\mathrm{F}$ & $\mathrm{M}$ & $\mathrm{F}$ & $\mathrm{M}$ & $\mathrm{F}$ & $\mathrm{M}$ & $\mathrm{F}$ & \\
\hline Strongly disagree & & & & & 1 & & & & 1 \\
\hline Disagree & & & 3 & 3 & & & 1 & & 7 \\
\hline Not sure & & $\mathbf{1}$ & & $\mathbf{4}$ & & $\mathbf{2}$ & $\mathbf{3}$ & & $\mathbf{1 0}$ \\
\hline Agree & & & 1 & 2 & & & & 1 & 4 \\
\hline Strongly agree & 1 & & & & 1 & & & & 2 \\
\hline Total & 1 & 1 & 4 & 9 & 2 & 2 & 4 & 1 & 24 \\
\hline
\end{tabular}

Confidence in using the language is considered critical for effective delivery in classroom as mentioned by Mariage, Englert, \& Garmon (2000) earlier.

The feedback on whether they can teach or conduct classes in English revealed the same results (see Table 10 below). This reflects what they felt about their confidence reported earlier (Table 9).

Table 10: Teachers' Perception of whether they can teach or conduct classes using English

\begin{tabular}{|l|l|l|l|l|l|l|l|l|l|l|}
\hline \multirow{2}{*}{} & \multicolumn{9}{|l|}{ Years of teaching experience } \\
\cline { 2 - 11 } & $1-5$ & & $6-10$ & \multicolumn{2}{l|}{$11-15$} & \multicolumn{2}{l|}{$>15$} & Total \\
\cline { 2 - 11 } & $\mathrm{M}$ & $\mathrm{F}$ & $\mathrm{M}$ & $\mathrm{F}$ & $\mathrm{M}$ & $\mathrm{F}$ & $\mathrm{M}$ & $\mathrm{F}$ & \\
\hline Strongly disagree & & & & & & & & & \\
\hline Disagree & & & 2 & 5 & & & 1 & & 8 \\
\hline Not sure & & 1 & 1 & 4 & 1 & 2 & 1 & & 10 \\
\hline Agree & 1 & & 1 & & & & 2 & 1 & 5 \\
\hline Strongly agree & & & & & 1 & & & & 1 \\
\hline Total & 1 & 1 & 4 & 9 & 2 & 2 & 4 & 1 & 24 \\
\hline
\end{tabular}

Participants' expectations and level of motivation in attending the course were also elicited. Generally, the participants expressed that they were happy to have been selected as participants of the course, e.g. "it is good to be a participant in this English class"; "I am very glad to be a member in this class". It was also observed that the reason for this was mainly to "improve myself to use this language". Many participants shared this objective by stating "I hope this course would improve me to converse in English effectively" or "Saya berharap selepas kursus ini, saya boleh bertutur dengan 
fasih dan lancar dalam Bahasa Inggeris" (I hope after this course, I can converse in English more fluently) (see Table 11 for more responses).

Generally, the teachers were motivated in attending the course and perhaps had perceived the significance and advantages of attending such a course for their career development as suggested by Nyakundi (2012).

Table 11: Teachers' Expectations at the beginning of the course

Comment/suggestion for the course:

- It is good to be a participant in this English class because I can improve myself to use this language

- I hope this course would motivate me to converse in English efficiently

- Jalankan kursus secara relax dan tiada tekanan

- Santai dan ceria

- Saya berharap selepas mengikuti kursus ini, saya boleh bertutur dgn fasih dan lancar dalam bahasa inggeris

- Kursus ini menarik dan tenaga pengajar sangat optimis untuk menggalakkan guru-guru berbahasa dalam BI

- I like this class, only on Wednesdays and Thursdays and not more than $1 \frac{1}{2}$ hours

- Can I connect with you to learn this language by Facebook or email or can you group for us in Facebook, so can monitor easily the development

- I am very glad to be a member in this class

In the first activity, the participants were asked to brainstorm on their challenges in teaching Science and Mathematics. Their responses revealed a more specific set of challenges they faced in teaching these subjects in English. These challenges could be categorized into four: Teaching \& Learning or Communication, Environment, Policy and Students. A summary of the challenges is shown in the table below.

Table 12: Teachers' Expectations of Challenges at the beginning of the course

\begin{tabular}{|l|l|}
\hline Teaching-learning (Communication) & Environment \\
\hline $\begin{array}{l}\text { Teacher and student }- \text { not confident to use } \\
\text { English }\end{array}$ & $\begin{array}{l}\text { Environment does not support use of English } \\
\text { - } \begin{array}{l}\text { Surrounding environment does not support } \\
\text { teachers who speak English }\end{array} \\
\text { Repeat the lesson twice }-\left(2^{\text {nd }} \text { time in Malay) }-\right. \\
\begin{array}{l}\text { waste time } \\
\text { Difficult to elaborate the lesson }\end{array}\end{array}$ \\
\hline $\begin{array}{l}\text { Poor in grammar } \\
\text { Policy }\end{array}$ & \begin{tabular}{l} 
Students \\
\hline Education policy - always change
\end{tabular} \\
& $\begin{array}{l}\text { Students don't understand } \\
\text { learning (difficult to understand) }\end{array}$ \\
\hline
\end{tabular}

The second set of questionnaires was administered after about $1 \frac{1}{2}$ month into the course. Feedback from the participants was again elicited mainly to determine whether or not the content of the course suited the participants and if any adjustments were needed to make the course more useful or if their 
initial challenges (as reported after Activity 1) were reduced/minimized. The responses obtained (see Table 13 below) suggested that the participants wanted more speaking activities, such as presentations or basically "talking sessions". These highlight participants' awareness of their own deficiencies or needs and their willingness to improve this skill. This reflected their earlier perception of their speaking competency. The participants also expressed a few 'learning' challenges such as requesting for the pace of the course to be adjusted to suit the participants' learning pace.

Table 13: Teachers' Expectations halfway through the course

\begin{tabular}{|c|c|c|}
\hline Q1 & \multicolumn{2}{|c|}{ I would like to suggest the following things to be covered in the second half of this course: } \\
\hline & Activities & Learning factors \\
\hline & $\begin{array}{l}\text { isten the national geographic article or any news and then } \\
\text { articipants has to explain what they have or understand } \\
\text { nore communication between participant } \\
\text { nore activity to improve or increase talking session } \\
\text { nore presentation } \\
\text { nore student contact } \\
\text { nore fun activities } \\
\text { ctivities that make us use English more often } \\
\text { earn phrases as routine as a teacher } \\
\text { ive more hand-out of everyday conversation } \\
\text { jive examples of phrases use when we present in class }\end{array}$ & $\begin{array}{l}\text { - not too fast, need time to digest } \\
\text { - } \quad \text { no coursework but workshop }\end{array}$ \\
\hline
\end{tabular}

Based on this survey, the participants requested more activities that provided opportunities to practice their speaking skills and desired these to be conducted in a 'fun' way. They also wanted more input on common expressions that can be used in presentations and oral communication, input on conversation, routing as teacher plus phrases to be used in class. This perhaps reflects teachers' awareness of the importance of 'interaction' as part of effective teaching as discussed by Crosnoe, Johnson, \& Elder (2004).

The third set of questionnaires was given to the participants at the end of the course. Feedback on aspects of the course that they liked, difficulties faced during the course and aspects of the course that could be improved were elicited.

From the analysis of the responses (see Table 14), the participants generally gave positive feedback on several aspects of the course. In terms of the content and activities, they especially appreciated those that provided them with opportunities to practice their speaking and communication skills. A few also found the language input (instructional language, question tags and grammar) and the materials used helpful and interesting. The opportunity to interact with the trainers was also regarded as a positive aspect of the course as this provided them with more instances for improving their speaking skills. 
Table 14: Teachers' Expectations at the end of the course: Aspects they liked

\begin{tabular}{|c|c|}
\hline $\begin{array}{l}\text { - } \quad \text { Interaksi antara pensyarah } \\
\text { - } \quad \text { Penceramah yang baik, mengajar contoh2 classroom } \\
\text { - } \quad \text { Cheerful coordinator } \\
\text { - } \quad \text { Banyak ruang untuk bercakap sesama rakan dlm BI } \\
\text { - } \quad \text { Instruction, question tags } \\
\text { - } \quad \text { Bahmugian grammar yang membantu } \\
\text { - } \quad \text { Semua orang diberi peluang untuk bercakap di } \\
\text { - hadapan kelas } \\
\text { Guru-guru dapat sama-sama berinteraksi/bertutur } \\
\text { dlm BI }\end{array}$ & $\begin{array}{l}\text { - } \quad \text { Presentation, all teacher can talk } \\
\text { - } \quad \text { Komunikasi dalam BI bersama rakan sekerja } \\
\text { - } \quad \text { Aktiviti dan bahan yang diberi menarik dan } \\
\text { dapat menambah pengetahuan } \\
\text { - Penceramah yang baik } \\
\text { - Communication and presentation } \\
\text { - Bengkel } \\
\text { - Kandungan kursus dan pensyarah yang } \\
\text { sangat supportive }\end{array}$ \\
\hline
\end{tabular}

In contrast, feedback regarding challenges faced revealed a different aspect of the course (see Table 15 below). These concerned the implementation and content of the course. Because the course was conducted after school hours, almost all the participants commented on the time and duration of the course. They reported on being exhausted and not being able to give full attention to the course. This, they felt affected their performance as well as their attendance. Many also felt that the duration of the course was insufficient. Only a few gave challenges that were related to the objective of the course; that is, they felt that they still needed more input on vocabulary (perhaps, those related to teaching their subjects).

Table 15: Teachers' Expectations at the end of the course: Challenges faced

\begin{tabular}{|c|c|c|}
\hline Implementation of course & & Course content \\
\hline $\begin{array}{l}\text { Masa yang terhad dan } \\
\text { waktu yang tidak betul- } \\
\text { betul tenang } \\
\text { Masa kursus bertindih } \\
\text { dengan beban kerja yang } \\
\text { sedia ada } \\
\text { Time of the course, in the } \\
\text { evening, usually we are } \\
\text { exhausted because of the } \\
\text { pack schedule during the } \\
\text { day } \\
\text { Kadang-kadang beban } \\
\text { kerja yang banyak, } \\
\text { mengurangkan focus } \\
\text { semasa dalam kelas } \\
\text { Burden of work, no time } \\
\text { to revise } \\
\text { Masa kursus }\end{array}$ & 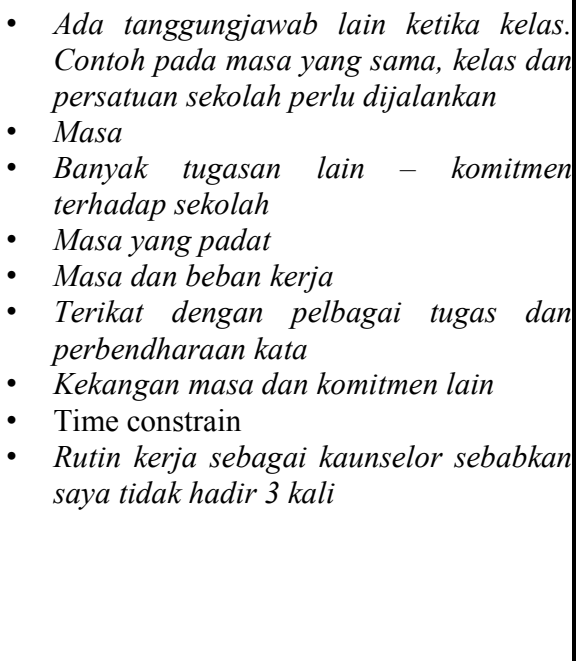 & $\begin{array}{l}\text { - Lack of vocab } \\
\text { Lack vocabulary/time not } \\
\text { enough }\end{array}$ \\
\hline
\end{tabular}


The participants also gave a few suggestions for improvements to the course. The main suggestion was to include more speaking activities as well as activities to increase their confidence, more classroom related tasks and less focus on grammar (see table below).

Table 16: Teachers' Expectations at the end of the course: Aspects that can be improved

\begin{tabular}{|c|c|}
\hline aspect of this course that can be improved: & \\
\hline $\begin{array}{l}\text { Rakaman pertuturan BI supaya menguji } \\
\text { keupayaan dalam pemahaman } \\
\text { - More discuss relate to our lesson } \\
\text { activity with playing or games } \\
\text { Allowing the participants speaking in 'market } \\
\text { English' and the lecturer correcting them. In this } \\
\text { way, the participants will have more confident in } \\
\text { speaking English and not afraid to make mistake }\end{array}$ & $\begin{array}{l}\text { - Elakkan mengadakan kursus pada hari sabtu } \\
\text { - Tidak perlu penekanan pada grammar or } \\
\text { rules } \\
\text { - Tempat kursus tidak terlampau luas } \\
\text { - } \text { Penye special time for the course } \\
\text { - Lebihkan presentation agar mutu 'speaking' } \\
\text { - Sediakan lebih banyak 'public speaking, }\end{array}$ \\
\hline
\end{tabular}

Responses from the five trainers were also obtained. They all agreed that there was active participation from the participants. This was mainly due to the format of the activities designed, which were mainly learner-centred, aimed at maximizing participation by the course participants. It was also observed that there could be more speaking activities which will help build teachers' confidence. However, the trainers also commented on the attendance of a few of the participants. This may be due to the comments given by the teachers earlier in terms of the time and duration of the course. Due to their many commitments at school, a few teachers were unable to give their full commitment to the course.

Table 17: Trainers' observations

\begin{tabular}{|l|l|}
\hline Observations by the trainers: & \multicolumn{1}{|c|}{ No of trainers: 5} \\
\hline $\begin{array}{l}\text { Positive: } \\
\text { Active participation in most activities }\end{array}$ & Negative: \\
Learner-centred activities encouraged & \\
participation & \\
$\quad$ Wanted more 'speaking' practice & \\
\hline
\end{tabular}

In general, although the participants expressed that they wanted more speaking activities, it can be surmised that they had benefited from the course and had gained a certain level of confidence in using English. The teachers found the three-month course useful and appreciated the commitment shown by the trainers. They even suggested more sessions to be included in the course. With regard to the implementation of the course, discussion with the school administrators about the time and duration of the course, and giving special consideration to teachers selected to attend it in terms of their other school commitments could help reduce their anxiety and increase their motivation and commitment.

It is acknowledged, however, on the part of the trainers that a once-a-week three-month long course may have contributed in some way to the overall confidence and improvements of the teachers in their daily teaching tasks. To what extent the course had helped the teachers was not investigated, 
which can be considered as one of the limitations of this study. Nevertheless, it was clear that the teachers' motivation was sustained throughout the course (except for the problem with attendance) and that more similar courses can and should be organized for teachers (see Alam and Farid, 2011). The fact that the teachers themselves had given suggestions on the content of the course also reflects what Knowles (1984) had argued about adult learning with regard to their self-concept and readiness to learn.

\section{CONCLUSION}

The participants were generally very positive about the course. However, the general implementation of the course could be improved so as to increase participation and maximize 'uptake' by the participants.

\section{REFERENCES}

Adeyinka, A., Asabi, O. and Adedotun, O. (2013). Teachers`Motivation on Students` Performance in Mathematics in Government Secondary Schools. International Journal of Humanities and Social Science Invention. Volume 2, Issue 5, p.35-41.

Alam, M. T. and Farid, S. (2011). Factors Affecting Teachers Motivation. International Journal of Business and Social Science, Vol. 2 No. 1, p. 298-304.

Crosnoe, R., Johnson, M.K., \& Elder, G.H. (2004). Intergenerational bonding in school: The behavioral and contextual correlates of student-teacher relationships. Sociology of Education, $77(1), 60-81$

Council of Ministers of Education, Canada (CMEC). (2013). Speaking for Excellence: Language Competencies for Effective Teaching Practice.

http://www.cmec.ca/Publications/Lists/Publications/Attachments/320/Speaking_for_Excellence .pdf

Eslami, Z. R. and Fatahi, A. (2008). Teachers' Sense of Self-Efficacy, English Proficiency, and Instructional Strategies: A Study of Nonnative EFL Teachers in Iran. The Electronic Journal for English as a Second Language, Volume 11, Number 4.

Pajares, F. (2002). Self-efficacy beliefs in academic contexts: An outline. http://des.emory.edu/mfp/efftalk.html.

Ling, J.2013.Teachers to help achieve Vision 2020. http://www.theborneopost.com/2013/05/22/teachers-to-help-achieve-vision2020/\#ixzz3LSdOvfeh

Mariage, T.V., Englert, C.S., \& Garmon, M.A. (2000). The teacher as "more knowledgeable other" in assisting literacy learning with special needs students. Reading \& Writing Quarterly, 16(4), 299-336. 
Nyakundi, T. K. (2012). Factors affecting teacher motivation in public secondary Schools in Thika West District, Kiambu County. Unpublished Master Thesis. School of Education Kenyatta University.

Knowles, M. (1984). Andragogy in Action. San Francisco: Jossey-Bass. 